\title{
Relationship between serum iron level and febrile convulsion in children.
}

\author{
Ayşe Tuğba Kartal ${ }^{1}$ and Zeynep Çağla Mutlu \\ ${ }^{1}$ Ankara University Faculty of Medicine, Division of Pediatric Neurology, Ankara, Turkey. \\ ${ }^{2}$ Kütahya Parkhayat Hospital, Department of Pediatrics, Kütahya, Turkey.
}

Key words: febrile convulsion; ferritin; fever; hemoglobin; iron.

\begin{abstract}
The aim of the present study was to evaluate the relationship between febrile convulsion, serum iron levels and whole blood parameters. This cross-sectional case-control study included patients aged 6 months- 6 years-old brought to the department of pediatrics of Kütahya ParkHayat Hospital with febrile convulsions between January 2015 and December 2019. The patients were divided into two groups as: febrile with convulsions (study group; $\mathrm{n}=47$ ) and febrile without convulsions (control group; $n=35$ ). Both groups were age and sex-matched. Some blood parameters such as mean serum iron, ferritin, $\mathrm{Hb}$ and MCV levels were used to compare the groups. Mean serum iron levels of the study and control groups were $33.7 \pm 2.1 \mu \mathrm{g} / \mathrm{dL}$ and $56.3 \pm 7.4 \mu \mathrm{g} / \mathrm{dL}$ $(\mathrm{p}<0.05)$, and serum ferritin levels were $27.3 \pm 6.2 \mathrm{ng} / \mathrm{mL}$ and $31.1 \pm 2.1 \mathrm{ng} /$ $\mathrm{mL}(\mathrm{p}>0.05)$, respectively. Mean hemoglobin levels of the study and control groups were $10.6 \pm 1.7 \mathrm{~g} / \mathrm{dL}$ and $11.1 \pm 1.4 \mathrm{~g} / \mathrm{dL}(\mathrm{p}<0.05)$, and mean MCV levels were $71.1 \pm 1.2 \mathrm{fL}$ and $73.2 \pm 1.1 \mathrm{fL}(\mathrm{p}>0.05)$, respectively. In the light of the findings of this study, the low serum iron and ferritin levels may be reinforcing factors for developing febrile convulsion. However, multicentre studies with more patients are needed to reach a precise conclusion.
\end{abstract}




\title{
Relación entre el nivel de hierro sérico y convulsiones febriles en niños.
}

\author{
Invest Clin 2021; 62 (2): 112-118
}

Palabras clave: convulsión febril; ferritina; fiebre; hemoglobina; hierro.

Resumen. El objetivo del presente estudio fue evaluar la relación entre la convulsión febril, el nivel de hierro en suero y los parámetros de sangre total. Este estudio transversal de casos y controles incluyó pacientes de 6 meses a 6 años llevados a consulta al departamento de pediatría del Hospital Kütahya ParkHayat con convulsiones febriles entre enero de 2015 y diciembre de 2019. Los pacientes se dividieron en dos grupos: pacientes con convulsiones febriles (grupo estudio; $\mathrm{n}=47$ ) y pacientes febriles sin convulsiones (grupo control; $\mathrm{n}=$ 35). Ambos grupos se emparejaron por edad y sexo. Para comparar los grupos se utilizaron algunos parámetros sanguíneos, como los niveles medios de hierro sérico, ferritina, Hb y MCV. Los niveles medios de hierro en suero de los grupos de estudio y control se encontraron como 33,7 $\pm 2,1 \mu \mathrm{g} / \mathrm{dL} ; 56,3 \pm 7,4 \mu \mathrm{g} /$ $\mathrm{dL}(\mathrm{p}<0,05)$, respectivamente. Los niveles de ferritina en suero fueron 27,3 $\pm 6,2 \mathrm{ng} / \mathrm{mL} ; 31,1 \pm 2,1 \mathrm{ng} / \mathrm{mL}(\mathrm{p}>0,05)$, respectivamente. Los niveles medios de hemoglobina del estudio y del grupo control fueron 10,6 $\pm 1.7 \mathrm{~g} /$ $\mathrm{dL} ; 11,1 \pm 1,4 \mathrm{~g} / \mathrm{dLl}(\mathrm{p}<0,05)$, respectivamente, y los niveles medios de MCV fueron 71,1 $\pm 1,2 \mathrm{fL} ; 73,2 \pm 1,1 \mathrm{fL}(\mathrm{p}>0,05)$, respectivamente. A la luz de los resultados de este estudio, los bajos niveles de hierro y ferritina en suero pueden ser factores de refuerzo para desarrollar convulsiones febriles. Sin embargoo, se necesitan estudios multicéntricos con más pacientes para tomar una decisión precisa.

Received: 26-07-2020 Accepted: 17-01-2021

\section{INTRODUCTION}

The most common type of seizure in children is febrile convulsion, which is generally characterized by a temperature of 38 ${ }^{\circ} \mathrm{C}$ or higher that occurs in children aged 6 months to 6 years and who do not have evidence of intracranial infection, head trauma, electrolyte imbalance, hypoglycemia and drug use. Febrile convulsion peaks at around 18 months, and its annual incidence is $2 \%-5 \%(1)$. Febrile convulsion is classified into simple and complex types. Simple febrile convulsion lasts for $<15$ min within a 24-hour period, whereas the complex type lasts for $>15 \mathrm{~min}$ and occurs more than once within a 24 -hour period (2-4).

Iron deficiency is the most common nutritional disorder worldwide, and it is most frequently observed in children aged 6-24 months and in adolescents (5). Clinical findings depend on the severity of anemia, age, and presence of comorbidities. Iron is involved in the synthesis of many proteins and enzymes, and it also participates in the electron transport system (6). Unexplained fatigue and pallor of the conjunctivae and skin are the most common symptoms of iron de- 
ficiency anemia (7). In some cases, diaǵnosis is based only on serum iron and hemoglobin ( $\mathrm{Hb})$ levels (8). In severe cases, cardiac systolic murmur, hemodynamic instability, breath-holding attacks, dyspnea at rest, and syncope can be observed (8). In prolonged cases, changes in epithelial cells, such as atrophic glossitis, cheilitis, dry mouth and hair loss, can be seen (9). Additionally, some neurological problems (e.g., impaired psychomotor and mental development) and attention-deficit/hyperactivity disorder may be found (10).

In recent studies, the relationship between iron deficiency and febrile convulsion draws attention $(11,12)$. It has been shown that iron affects energy metabolism, the neurotransmitter system and myelin development in the brain. These effects of iron deficiency may negatively affect brain development (13). Additionally, according to some authors, excessive amounts of proinflammatory cytokines are released during fever, and this phenomenon may aggravate the negative effects of iron deficiency toward the brain $(6,13,14)$. However, there are not enough studies to support this relationship yet.

The aim of the present study was to evaluate the relationship between febrile convulsion and serum iron level, and some blood parameters.

\section{MATERIALS AND METHODS}

This cross-sectional case-control study included patients aged 6 months to 6 years that were taken to the department of pediatrics of ParkHayat Hospital with febrile convulsions between January 2015 and December 2019. The electronic medical recording system and patients' files were used to get information about the patients, and the cases were selected according to the inclusion and exclusion criteria. The patients were divided into two groups as: with febrile convulsion (study group; $\mathrm{n}=47$ ) and fever without convulsion (control group; $n=35$ ).
Febrile convulsion was diagnosed according to the American Academy of Pediatrics guidelines. Febrile convulsions are defined as a type of seizure that occurs in children between 6 months - 6 years olds, associated with fever (greater than $38^{\circ} \mathrm{C}$ ), but without acute intracranial infection, metabolic disturbance or long-term neurological conditions (15).

Inclusion and exclusion criteria for the febrile convulsion group: patients aged 6 months to 6 years, and patients with a first simple convulsion episode were included to the study. Children under 6 months and over 6 years of age, patients with two or more complex febrile convulsions, pchildren that received iron treatment in the last three months, with chronic inflammatory disease, neurodevelopmental retardation, hematological disease, intestinal malabsorption syndrome and with missing data, were excluded from the study.

Inclusion and exclusion criteria for control group: patients with the same age and gender who were brought to the department of pediatrics due to any febrile illness (without any seizure) were included to the study. The patients with central nervous system infection or who had any seizure were excluded from the study.

Whole blood parameters (hemoglobin (Hb), mean corpuscular volume (MCV), red cell distribution width (RDW)) were measured with an automatic blood count device LH 750 (Beckman Coulter, Miami, USA). Iron and ferritin were determined with a Cobas C501 (ROCHE Berlin, Germany) analyzer. Anemia was defined by $\mathrm{Hb}$ levels of $<10.5$ $\mathrm{g} / \mathrm{dL}$ in patients aged 6 months to 2 years and by $\mathrm{Hb}$ levels of $<11.5 \mathrm{~g} / \mathrm{dL}$ in patients aged $2-5$ years (16). The normal ferritin level was set at $>12 \mathrm{ng} / \mathrm{mL}$, and the normal serum iron level was considered to be $>40 \mu \mathrm{g}$ / $\mathrm{dL}$ for children aged $<1$ year and $>50 \mu \mathrm{g} / \mathrm{dL}$ for those aged $>1$ year (17).

The study protocol was approved by the local ethics committee and conducted according to the Helsinki declaration. Given 
by Ethics Committee of Kütahya University of Health Sciences (2020/07-03).

\section{Statistic analysis}

Data analysis was performed by using the IBM SPSS 21.0 package program. Continuous variables were expressed as means \pm standard deviations and the qualitative variables in absolute frequiencies and percentages. The independent samples t-Test and chi-square tests were used to compare the groups. A p-value less than 0.05 was considered statistically significant.

\section{RESULTS}

The demographic and laboratory characteristics of the participants in the study are presented in Table I. There were no differences $(p \leq 0.05)$ in the mean age and the male/female ratio of the study and control groups. Mean serum iron level of the study and control groups was found as $33.7 \pm 2.1$ $\mu \mathrm{g} / \mathrm{dL}$ and $56.3 \pm 7.4 \mu \mathrm{g} / \mathrm{dL}(\mathrm{p}<0.05)$, respectively, and serum ferritin level was found as $27.3 \pm 6.2 \mathrm{ng} / \mathrm{mL}$ and $31.1 \pm 2.1 \mathrm{ng} /$ $\mathrm{mL}(\mathrm{p}>0.05)$, respectively. Mean hemoglo- bin level of the study and control groups was found as $10.6 \pm 1.7 \mathrm{~g} / \mathrm{dL}$ and $11.1 \pm 1.4$ $\hat{\mathrm{g}} / \mathrm{dL}(\mathrm{p}<0.05)$, respectively, and mean MCV level was found as $71.1 \pm 1.2 \mathrm{fL}$ and $73.2 \pm$ $1.1 \mathrm{fL}(\mathrm{p}>0.05)$, respectively.

Fever etiologies of febrile convulsion and control groups were compared in Table II.

\section{DISCUSSION}

Iron has many biological effects, and it is involved in important neurological processes, such as neurotransmitter metabolism, myelin formation, and brain energy metabolism (18). According to some experimental studies, in the case of iron deficiency, along with that of gamma-aminobutyric acid, iron concentration decreases in some brain regions (hypothalamus, mesencephalon, thalamus, hippocampus, and corpus striatum) $(19,20)$.

In the present study, serum ferritin and iron levels were lower in the febrile convulsion group than in the control group; although a significant difference was observed only for iron. Similar results were found by Hameed et al. and Fallah et al. Their results

TABLE I

THE DEMOGRAPHIC AND LABORATORY CHARACTERISTICS OF THE STUDY PARTICIPANTS.

\begin{tabular}{lclc}
\multicolumn{1}{c}{ Variable } & $\begin{array}{c}\text { Febrile Convulsion Group (47) } \\
\dot{\mathrm{X}} \pm \mathrm{SD}\end{array}$ & $\begin{array}{c}\text { Control Group (35) } \\
\dot{\mathrm{X}} \pm \mathrm{SD}\end{array}$ & $\mathrm{p}$ \\
\hline $\begin{array}{l}\text { Age (months) } \\
\text { Gender \% (n) }\end{array}$ & $24.3 \pm 1.1$ & $25.4 \pm 2.1$ & 0.411 \\
$\quad$ Female & $59.6(28)$ & $57.1(20)$ & 0.337 \\
$\quad$ Male & $40.4(19)$ & $42.9(15)$ & \\
Hb $(\mathrm{g} / \mathrm{dL})$ & $10.4 \pm 1.7$ & $11.1 \pm 1.4$ & 0.031 \\
$\mathrm{MCV}(\mathrm{fL})$ & $71.1 \pm 1.2$ & $73.2 \pm 1.1$ & 0.401 \\
RDW $(\%)$ & $15.4 \pm 1.3$ & $14.8 \pm 1.1$ & 0.356 \\
Ferritin $(\mathrm{ng} / \mathrm{mL})$ & $27.3 \pm 6.2$ & $31.1 \pm 2.1$ & 0.053 \\
Iron $(\mu \mathrm{g} / \mathrm{dL})$ & $33.7 \pm 2.1$ & $56.3 \pm 7.4$ & 0.002 \\
\hline
\end{tabular}

(): Number of cases.

$\dot{\mathrm{X}} \pm \mathrm{SD}:$ mean \pm standard deviation.

Hb: hemoglobin; MCV: mean corpuscular volume; RDW: red cell distribution width.

Vol. 62(2): $112-118,2021$ 
TABLE II

COMPARISON OF FEVER ETIOLOGY OF GROUPS.

\begin{tabular}{lccc}
\hline \multicolumn{1}{c}{ Fever etiology } & $\begin{array}{c}\text { Febrile Convulsion Group (47) } \\
\text { \% (n) }\end{array}$ & $\begin{array}{c}\text { Control Group (35) } \\
\%(\mathrm{n})\end{array}$ & $\mathrm{p}$ \\
\hline Upper respiratory tract infection & $44,6(21)$ & $42,8(15)$ & 0.413 \\
Acute otitis media & $19,1(9)$ & $20(7)$ & 0.447 \\
Lower respiratory tract infection & $8,5(4)$ & $11,4(4)$ & 0.323 \\
Gastroenteritis & $17(8)$ & $17,1(6)$ & 0.319 \\
Urinary tract infection & $4,2(2)$ & $2,8(1)$ & 0.367 \\
Influenza & $6,3(3)$ & $5,7(2)$ & 0.403 \\
\hline
\end{tabular}

(n ): Number of cases.

showed that serum ferritin and iron levels were significantly lower in the febrile convulsion group than in the control group (15, 21). By contrast, Kobrinsky et al. found that serum ferritin level was lower in the control group consisting of febrile patients without convulsion, and they suggested that iron deficiency is a protective factor for febrile convulsion in acute febrile infection (22). We speculate that the number of participants, the case selection, and the regional nutritional habits of patients (the patients included in our study has a diet unique to the Mediterranean cuisine) may have caused the differences in the results obtained in the above studies.

In terms of $\mathrm{Hb}$ and MCV values, conflicting results were reported by different authors who compared patients who had febrile convulsion with those who had fever without convulsion $(1,23)$. In a Turkey-based study, Nalbantoglu et al. compared 94 patients with febrile convulsion and 70 individuals with fever without convulsion, and they found that the groups significantly differed in terms of $\mathrm{Hb}$ levels. Mean corpuscular volume value was lower in the febrile convulsion group, but this difference was not significant (24). In another study carried out by Aziz et al. from Pakistan, $\mathrm{Hb}$ and MCV values were significantly lower in patients with febrile convulsion (25). Compared with these studies, the India-based study conducted by Mehta et $a l$. did not find any significant difference between the groups, although the $\mathrm{Hb}$ and $\mathrm{MCV}$ values were lower in febrile convulsion group (26). In our study, Hb value was significantly lower in the patients with febrile convulsion, a finding that is similar to that of the first two studies. Mean corpuscular volume value was also found to be lower in the febrile convulsion group, but this difference was not significant. The differences in the results of the abovementioned studies were possibly due to the number of patients included.

According to the literature, febrile convulsion usually develops due to an upper respiratory infection $(27,28)$. Consistent with this information, upper respiratory tract infections were the most common etiologic factor causing febrile convulsion in the study of Chung et al. (33\%) and Delpisheh et al. $(42,3 \%)(29,30)$. Our results are also in agreement with the findings of these studies.

Our study has limitations, including its retrospective nature, its relatively few and heterogeneous participants, its inclusion of ferritin, which is an acute phase reactant, and its failure to account for the patients' nutritional habits.

On the basis of the present findings, low serum iron and ferritin levels may be considered as reinforcing factors for the development of febrile convulsion. Therefore, 
the evaluation of the iron status should be encouraged in children with febrile convulsion, and iron supplementation is possibly beneficial in the treatment and prevention of febrile convulsion in children.

\section{REFERENCES}

1. Gencer H, Kafadar I, Köse G, Yıldırmak Y. Relationship of febrile convulsion with iron deficiency anemia and zinc deficiency. JAREM 2016;6:94-97.

2. Laino D, Mencaroni E, Esposito S. Management of pediatric febrile seizures. Int $\mathrm{J}$ Environ Res Public Health 2018;15(10):2232.

3. Leung AK, Hon KL, Leung TN. Febrile seizures: an overview. Drugs Context 2018; 7:e212536.

4. Yousefichaijan P, Eghbali A, Rafeie M, Sharafkhah M, Zolfi M, Firouzifar M. The relationship between iron deficiency anemia and simple febrile convulsion in children. $\mathrm{J}$ Pediatr Neurosei 2014;9(2):110-114.

5. Karimi P, Sayehmiri K, Azami M, Tardeh $Z$. The association between iron deficiency anemia and febrile seizure. Int $\mathrm{J}$ Adolese Med Health 2019;13:e20190083.

6. Beard J. Iron deficiency alters brain development and functioning. $\mathrm{J}$ Nutr 2013;133:1468-1472.

7. Lopez A, Cacoub P, Macdougall IC, PeyrinBiroulet L. Iron deficiency anemia. Lancet 2016;387(10021):907-916

8. Mattiello $\mathrm{V}$, Schmugge $M$, Hengartner $\mathrm{H}$, von der Weid N, Renella R; SPOG Pediatric Hematology Working Group. Diagnosis and management of iron deficiency in children with or without anemia: consensus recommendations of the SPOG Pediatric Hematology Working Group. Eur J Pediatr 2020;179(4):527-545.

9. Subramaniam G, Girish M. Iron deficiency anemia in children. Indian $\mathrm{J}$ Pediatr 2015;82(6):558-564.

10. Badaraceo ME, Siri MV, Pasquini JM. Oligodendrogenesis: the role of iron. Biofactors 2010;36(2):98-102.

11. Sharif MR, Kheirkhah D, Madani M, Kashani HH. The relationship between iron deficiency and febrile convulsion:
A case-control study. Glob J Health Sci 2015;8(2):85-89.

12. Bidabadi E, Mashouf M. Association between iron deficiency anemia and first febrile convulsion: A case-control study. Seizure 2009;18(5):347-351.

13. Vaswani RK, Dharaskar PG, Kulkarni S, Ghosh K. Iron deficiency as a risk factor for first febrile seizure. Indian Pediatr 2010;47(5):437-439.

14. Tanabe T, Suzuki S, Hara K. Cerebrospinal fluid and serum neuron- specific enolase after febrile seizures. Epilepsia 2001;42:504507.

15. Abdel Hameed ZA, El-Tellawy MM, Embaby M, Kamel YS. Relation of iron and zine deficiencies to the occurrence of febrile convulsions. J Pediatr Neurosei 2019;14(2):61-64.

16. Sharif MR, Kheirkhah D, Madani M, Kashani HH. The relationship between iron deficiency and febrile convulsion: a casecontrol study. Glob J Health Sci 2015 25;8(2):185-189.

17. Ghasemi F, Valizadeh F, Taee N. Iron-deficiency anemia in children with febrile seizure: a case-control study. Iran J Child Neurol 2014;8(2):38-44.

18. Ozaydin E, Arhan E, Cetinkaya B, Ozdel S, Değerliyurt A, Güven A, Köse G. Differences in iron deficiency anemia and mean platelet volume between children with simple and complex febrile seizures. Seizure 2012;21(3):211-214.

19. Beard JL, Unger EL, Bianco LE, Paul T, Rundle SE, Jones BC. Early postnatal iron repletion overeomes lasting effects of gestational iron deficiency in rats. J Nutr 2007;137(5):176-182.

20. Felt BT, Beard JL, Schallert T, Shao J, Aldridge JW, Connor JR, Georgieff MK, Lozoff B. Persistent neurochemical and behavioral abnormalities in adulthood despite early iron supplementation for perinatal iron deficiency anemia in rats. Behav Brain Res 2006;171(2):261-270.

21. Fallah R, Tirandazi B, Akhavan Karbasi S, Golestan M. Iron deficiency and iron deficiency anemia in children with febrile seizure. Iran J Ped Hematol Oncol 2013;3(1):200-203.

22. Kobrinsky NL, Yager JY, Cheang MS, Yatscoff RW, Tenenbein M. Does iron deficiency

Vol. 62(2): 112 - 118, 2021 
raise the seizure threshold? J Child Neurol 1995;10(2):105-109.

23. Ünver $O$, Sezer RG, Kibar AE, Ünver A, İpek İÖ, Bozaykut $\mathrm{A}$. The association between febrile seizures and iron deficiency anemia in childhood. JCAM 2015;6(1):5760.

24. Nalbantoğlu A, Nalbantoğlu B. The relationship between iron deficiency and febrile convulsion in children. Cukurova Med J 2019;44(3):1033-1039.

25. Aziz KT, Ahmed N, Naǵi AG. Iron deficiency anemia as risk factor for simple febrile seizures: a case control study. J Ayub Med Coll Abbottabad 2017;29(2):316-319.
26. Mehta S. To study the role of iron deficiency anemia in febrile seizures in children. EJPMR 2016;3(2):375-377.

27. Fetveit A. Assessment of febrile seizures in children. Eur J Pediatr 2008;167(1):17-27.

28. Patterson JL, Carapetian SA, Hageman JR, Kelley KR. Febrile seizures. Pediatr Ann 2013;42(12):249-254.

29. Chung S. Febrile seizures. Korean J Pediatr 2014;57(9):384-395.

30. Delpisheh A, Veisani Y, Sayehmiri K, Fayyazi A. Febrile seizures: etiology, prevalence, and geographical variation. Iran J Child Neurol 2014;8(3):30-37. 